\title{
2020 Cool-Season Forage Variety Recommendations for Florida ${ }^{1}$
}

\author{
A. R. Blount, M. Wallau, E. Rios, J. M. B. Vendramini, J. C. B. Dubeux, Md. A. Babar, K. E. \\ Kenworthy, M. Mulvaney, and K. H. Quesenberry²
}

\section{Introduction}

Perennial warm-season pasture grasses used in Florida become dormant in late fall and winter because of short days, cooler temperatures, and frosts. Many livestock producers may choose to establish cool-season annual pasture species to supplement their forage production. These plants are usually higher in total digestible nutrients (TDN) and crude protein (CP) than summer perennial grasses, translating into greater animal performance (Dubeux et al. 2016). Planting and growing these forage crops can involve considerable expense and are somewhat risky because rainfall is often unpredictable during the fall establishment period. The species and varieties for potential use vary in the distribution of production during the cooler months and in the type of soils where they are best adapted.

Many cool-season forages are also grown as silage crops or cover crops. Cool-season legumes like vetch and lupine can produce a significant amount of biomass and fix 40 to 80 $\mathrm{lb}$ of N/A. Similar characteristics in terms of productivity and disease resistance should be considered when planting those species as silage or cover crops. For those uses, delaying planting is sometimes recommended to avoid the need for irrigation early in the fall. However, that decision depends on intended use. If multiple silage cuttings are desired, planting may occur at the same time as normally recommended planting dates for grazing; however, harvesting must occur when plants are still in the vegetative stage to avoid potential freeze damage or winter kill of the stand. In some years, early planting for silage or cover cropping has made stands susceptible to diseases, insect pests, and lodging. Many producers cut back on seeding rates when planting cover crops. However, a fast soil cover is desirable for weed management (competition) and erosion control.

This publication provides the most up-to-date information on adapted cool-season forage varieties. The recommendation of varieties is based on multi-location, multi-year cultivar evaluation experiments that may include trials in Georgia and other states (https://georgiaforages.caes.uga. edu/species-and-varieties/variety-trials/forage-variety-trialinformation.html). For a virtual tour of the 2019-2020 Milk Check-off variety trial, see https://youtu.be/qpH_jeLGBPA.

1. This document is SS-AGR-84, one of a series of the Agronomy Department, UF/IFAS Extension. Original publication date September 2003. Revised June 2010, October 2011, December 2012, September 2013, September 2014, September 2017, September 2018, August 2019, and September 2020. Visit the EDIS website at https://edis.ifas.ufl.edu for the currently supported version of this publication.

2. A. R. Blount, professor, Agronomy Department, UF/IFAS North Florida Research and Education Center; M. Wallau, assistant professor, Agronomy Department; E. Rios, assistant professor, Agronomy Department; J. M. B. Vendramini, professor, Agronomy Department, UF/IFAS Range Cattle REC; J. C. B. Dubeux, associate professor, Agronomy Department, UF/IFAS NFREC; Md. A. Babar, assistant professor, Agronomy Department; K. E. Kenworthy, professor, Agronomy Department; M. Mulvaney, associate professor, Agronomy Department, UF/IFAS WFREC; and K. H. Quesenberry, professor emeritus, Agronomy Department; UF/IFAS Extension, Gainesville, FL 32611.

The use of trade names in this publication is solely for the purpose of providing specific information. UF/IFAS does not guarantee or warranty the products named, and references to them in this publication do not signify our approval to the exclusion of other products of suitable composition.

The Institute of Food and Agricultural Sciences (IFAS) is an Equal Opportunity Institution authorized to provide research, educational information and other services

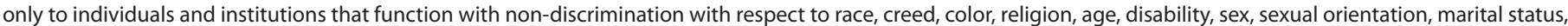

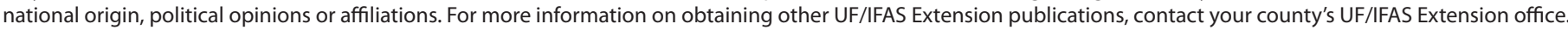
U.S. Department of Agriculture, UF/IFAS Extension Service, University of Florida, IFAS, Florida A \& M University Cooperative Extension Program, and Boards of County Commissioners Cooperating. Nick T. Place, dean for UF/IFAS Extension. 
Table 1 includes information about planting dates, seeding rates, and other considerations. If you have questions about a particular variety, contact your local UF/IFAS Extension agent for additional information (https://sfyl.ifas.ufl.edu/ find-your-local-office/).

\section{Recommended Cultivars} (Varieties)

\section{Alfalfa}

Alfalfa is usually grown as a winter short-term perennial in Florida, typically used for haylage, green chopping, or hay. Alfalfa requires good management practices for establishment and maintenance. It is not tolerant to flooding or soils with high water tables and requires a soil $\mathrm{pH}$ of 6.5 or greater. This species is not widely cultivated in Florida because it is difficult to produce timely hay cuttings with Florida's humid conditions. However, the cost of producing alfalfa haylage and silage has decreased in recent years, and this has made it a viable and cost-effective option as a highquality, conserved legume forage. Some new cultivars have been developed to tolerate a certain amount of grazing, but they are not as grazing-tolerant as other legume species, such as most of the clovers.

\section{RECOMMENDED VARIETIES}

Alfagraze 600RR (Roundup Ready) and Bulldog 805.

\section{Clover, Arrowleaf}

Arrowleaf clover is an annual species, similar to crimson clover in soil adaptation, management, and fertility requirements. It is mainly grown on heavier soils in northwestern Florida. Arrowleaf clover grows later in the spring than crimson clover.

\section{RECOMMENDED VARIETIES}

Blackhawk and Apache (for north and central Florida). Yuchi is not recommended because it is an older variety and is more susceptible to disease. Blackhawk and Apache have improved virus resistance compared to Yuchi.

\section{Clover, Ball}

Ball clover grows on a wide range of soil types, including poorly drained soils. Although it is well adapted, it is not considered to be a highly productive forage in Florida.

\section{RECOMMENDED VARIETIES}

Don and Grazer's Select. Pre-inoculated seed is recommended.

\section{Clover, Berseem}

Berseem clover has low bloat potential and is well adapted to many soil types in Florida, including more alkaline and wet soils. Care should be given to the management of berseem clover when grazed. It is advisable to graze at about 10 inches and leave a stubble height of 3-4 inches.

\section{RECOMMENDED VARIETIES}

Bigbee and Frosty.

\section{Clover, Crimson}

This clover is a reseeding annual adapted to fertile, well-drained soils. It has a relatively short grazing season. Crimson clover may be grown in combination with ryegrass or a small grain crop.

\section{RECOMMENDED VARIETIES}

Dixie and AU-Robin (seed availability may be limited).

\section{Clover, Red}

Red clover behaves as a winter annual under Florida conditions and usually does not reseed itself. It does not tolerate poorly drained soils. Red clover provides long-season forage production in north Florida.

\section{RECOMMENDED VARIETIES}

Barduro (mid-dormant, released by UF/IFAS), Red Ace, Southern Belle (non-dormant, released by UF/IFAS), and FL24D (resistant to 2,4-D herbicide, released by UF/IFAS).

Southern Belle is a non-dormant red clover. It offers earlier forage production and greater total-season forage yields than more dormant varieties. Barduro is a UF/IFAS red clover cultivar that is a mid-dormant type. Bulldog Red is also marketed in the southeastern United States, but data are limited on its performance in Florida. FL24D was released by UF/IFAS in 2016 and licensed to Grassland Oregon. Seed availability for FL24D red clover may still be limited.

\section{Clover, White}

White clover is usually a winter perennial but may act as an annual, depending on moisture conditions. It is adapted to moist soils throughout Florida and is moderately tolerant to acidity. Production and persistence of white clover can be limited by nematodes and other pests.

\section{RECOMMENDED VARIETIES}

Louisiana S-1, Ocoee (released by UF/IFAS, nematodetolerant), Osceola (released by UF/IFAS), Regal Ladino, 
and Regalgraze. Durana is also well adapted, has a prostrate growth habit, and persists well under grazing, but it has lower initial forage yields.

\section{Fescue, Tall}

In general, fescue is not recommended for Florida. It does not persist as a perennial, and small grains and ryegrass are more productive as cool-season annuals. A few producers have had limited success with Ga-5 when planted on low, wet clay soils in northwestern Florida.

\section{RECOMMENDED VARIETIES}

None.

\section{Lupine}

Lupine is an annual plant adapted to well-drained soils in northern and western Florida. It is an excellent cover crop. Seed supply has been low in recent years, and forage production has been limited by diseases and insects. Only sweet lupine varieties are suitable for forage.

\section{RECOMMENDED VARIETIES}

Tifblue. Frost and Tifwhite are also recommended; however, commercial seed production of these lupine varieties has been limited and seed is currently unavailable.

\section{Medic}

Medics are small-seeded legumes that grow on a wide range of soil types. Although they are well adapted, they are not considered to be highly productive forages in Florida.

\section{RECOMMENDED VARIETIES}

Armadillo burr and Devine little burr. Pre-inoculated seed is recommended.

\section{Oat}

Oat is very palatable but susceptible to freeze injury. Oat may be planted and grazed earlier than rye. Legend 567 and Horizon 720 were considered crown rust-resistant varieties, but rust has been reported in the past few years. In 2013, a new strain of crown rust was identified on all commercially available eastern oat varieties. Symptoms ranged from mild infection to early plant senescence. In grazing systems, crown rust resistance is less critical because rust inoculum is reduced by the grazing animal. Other commercially available varieties of oat are often very productive, although susceptible to crown rust. Early planting of susceptible varieties is not recommended. Few fungicides are labeled for use in grazing systems, and many have hay use limitations. Horizon 306 and RAM LA 99016 are excellent forage types that exhibit winter hardiness and good grain production, but they are susceptible to the new strain of crown rust that is prevalent statewide. Susceptible oat plantings may need to be scouted for rust and treated with legal fungicides, particularly if grown for silage or grain. Some varieties, such as NK-Coker 227, may be injured by Barley Yellow Dwarf Virus (BYDV), which is an aphid-transmitted virus. Typically, early-planted oat varieties grown for grazing are not sprayed with insecticides for aphid control. Grazing reduces populations of aphids but may not prevent early infection of BYDV in early-planted situations where warm fall weather prevails.

\section{RECOMMENDED VARIETIES}

Legend 567 (moderately crown rust-resistant), Horizon 720 (moderately resistant to crown rust), Horizon 306, Horizon 270 (crown rust-susceptible), and RAMLA 99016 (moderately crown rust-susceptible).

\section{Peas, Austrian Winter (Common)}

This annual legume is best suited to well-drained soils with high clay content.

\section{RECOMMENDED VARIETIES}

Common, Maple, and Whistler.

\section{Rye}

Rye is the small grain most widely used for winter grazing. Rye is more cold-tolerant than oat and generally produces more forage than either oat or wheat. If rye is planted very early in the season, there may be a decreased stand caused by various seedling diseases. Normally, rye developed from northern states produces little forage in late fall or early winter and tends to be severely damaged by leaf rust. Therefore, only plant varieties recommended for the southeastern United States. FL 401 is one of the earliest and most productive cool-season varieties, but it is generally more used for harvesting or cover cropping rather than for grazing because of the low leaf-to-stem ratio.

\section{RECOMMENDED VARIETIES}

FL 401 (for early grazing or use in blends), Kelly Grazer III (former FL 104), Wrens Abruzzi and late-forage season producers, developed in Oklahoma: Bates RS4, Elbon, Oklon, Maton, and Maton II.

\section{Ryegrass}

Ryegrass is a valuable mid- to late-winter and spring grazing crop for use on flatwoods soils or the heavier sandy loam soils in northwest Florida. Ryegrass may be seeded 
alone or with a small grain on a prepared seedbed, or overseeded onto permanent grass pastures. Seeding ryegrass with a small grain crop lengthens the grazing season.

\section{EARLY RECOMMENDED VARIETIES}

Attain, Big Boss, Diamond T, Earlyploid, Flying A, Frostproof (recently released by UF/IFAS), Lonestar*, Marshall*, Maximus ${ }^{\star}$, Nelson, Prine, TAMTBO, and Tetrastar.

\section{LATE RECOMMENDED VARIETIES}

Attain, Big Boss, Marshall*, Maximus ${ }^{\star}$, Nelson, Prine, TAMTBO, and Tetrastar.

\section{SEASON-LONG RECOMMENDED VARIETIES}

Attain, Big Boss, Diamond T, Earlyploid, Flying A, Lonestar $^{\star}$, Marshall $^{\star}$, Maximus ${ }^{\star}$, Nelson, Passerel Plus, Prine, TAMTBO, and Tetrastar.

These varieties were selected based on their recent threeyear, multi-location performance. Other ryegrass varieties, such as Centurion, Fria, Grits Diploid, Trinova, and Winterhawk, have also performed well in regional trials. Other new varieties may be suitable but have not been adequately evaluated in Florida.

${ }^{\star}$ Susceptible to rust and/or gray leaf spot.

\section{Sweetclover}

Sweetclover grows on slightly drier soils than white clover. It will not tolerate flooding. Sweetclover has an earlier but shorter grazing season than white clover. Sweetclover should be reseeded each year.

\section{RECOMMENDED VARIETIES}

None at present.

\section{Triticale}

Triticale is a cross between wheat and rye. It is well adapted to the southern United States and peninsular Florida. Triticale has the forage quality of wheat and the excellent disease resistance of rye. Triticale does not respond well to close grazing and therefore is recommended for haylage or silage if grown alone. If used for grazing, consider blending with ryegrass to promote a longer growing season. Use recommended varieties because there are triticale varieties sold in the state that are not adapted to Florida growing conditions and will not perform well.

\section{RECOMMENDED VARIETIES}

TriCal 342, TriCal $1143^{*}$, and Surge.
*Awnless varieties recommended for wildlife.

\section{Vetch}

Vetch grows best on well-drained, fertile, loamy soils. Although it is well adapted, it is not considered to be a highly productive in Florida.

\section{RECOMMENDED VARIETIES}

AU Early Cover, Cahaba White, Hairy, Merit, and Nova II. Commercial seed production of most vetch varieties is limited. It may be necessary to special order seed.

\section{Wheat}

Wheat is less susceptible to freeze injury than oat, but its productivity is generally lower than that of all other small grains in Florida. The main advantage of wheat is the possibility of dual-purpose use (i.e., grazing and grain), but grain production might be reduced when grazed, and quality is generally low for wheat grown in Florida. Wheat should not be planted for grazing before October 15. Only plant Hessian fly-resistant varieties for grazing.

\section{RECOMMENDED VARIETIES}

AGS 2024, AGS GrazeAll (AGS2027), Pioneer 26R10, Dyna-Gro Plantation.

\section{Important Considerations}

- Planting cool-season forages on a clean-tilled seedbed results in earlier and higher total forage production compared to overseeding on grass sod. If overseeding on bahiagrass, the sod should be disked to $30 \%$ disturbance. For overseeding on bermudagrass, a pasture drill or no-till drill can be used alone. Excess warm-season forage should always be removed as hay or by grazing before planting the cool-season forage.

- Success of winter pastures depends on adequate rainfall. This is especially true when overseeding.

- In central and south peninsular Florida, sod seeding (overseeding) of cool-season annuals into an established grass sod often fails because of insufficient soil moisture and warm-season grass competition. Sod seeding is generally not recommended unless irrigation is available or rainfall is adequate.

- Look for opportunities to plant on a clean-till seedbed, such as following vegetables or a row crop, after lifting sod, or in a pasture renovation program where the sod is plowed or turned under. 
- In south central Florida, small grains and ryegrass have been successfully grown on flatwoods in a pasture renovation program. If the sod is turned with a moldboard plow (late October-early November), with the soil harrowed, planted, and packed the same day, there will usually be enough moisture conserved to establish the new planting. If equipment and labor do not allow such a rapid progression of work, then it may be best to turn the sod, disk in early to mid-October, and wait for adequate rainfall before planting.

- Winter legumes are more dependable on the heavier clay soils of northwestern Florida or on sandy soils underlain by a clay layer compared to deep upland sands or sandy flatwoods. However, white clover and ryegrass overseeded can also be grown successfully on flatwoods soils in northeast Florida and south central Florida where the soil remains moist throughout the growing season.

- Remember to add the correct inoculant (nitrogen-fixing bacteria) to the legume seed before planting. Coated (already pre-inoculated) seed is sometimes available, but seed coatings with bacteria have a limited shelf life and may be costly compared to purchasing raw seed and inoculant separately and mixing just prior to planting. Be aware of proper storage for pre-inoculated seeds or inoculants; excess heat can kill bacteria.

\section{Reference}

Dubeux, J. C. B., N. DiLorenzo, A. Blount, C. Mackowiak, E. R. S. Santos, H. M. S. Silva, M. Ruiz-Moreno, and T. Schulmeister. 2016. "Animal Performance and Pasture Characteristics on Cool-season Annual Grass Mixtures in North Florida." Crop Sci. 56(5): 2841-2852. doi: 10.2135/ cropsci2016.03.0141. 
Table 1. Planting dates, seeding rates, planting depths, and grazing parameters for certain cool-season forage crops.

\begin{tabular}{|c|c|c|c|c|c|c|}
\hline \multirow{2}{*}{$\begin{array}{l}\text { Seed-propagated } \\
\text { Crops }^{1}\end{array}$} & \multirow[t]{2}{*}{ Planting Dates $^{2}$} & \multirow{2}{*}{$\begin{array}{l}\text { Seeding Rates } \\
\text { (Ib/A broadcast) }\end{array}$} & \multirow{2}{*}{$\begin{array}{l}\text { Seeding } \\
\text { Depth (in) }\end{array}$} & \multicolumn{2}{|c|}{ Grazing Height (in) } & \multirow[t]{2}{*}{ Rest Period } \\
\hline & & & & Begin & End & \\
\hline Alfalfa & Oct. 1-Nov. 15 & $15-20$ & $1 / 4-1 / 2$ & $10-16$ & $3-4$ & $\begin{array}{l}\text { Hay: } 35-40 \\
\text { Grazing: } 15-30\end{array}$ \\
\hline Clover, Arrowleaf & Oct. 1-Nov. 15 & $8-12$ & $0-1 / 2$ & $8-10$ & $3-5$ & $10-20$ \\
\hline Clover, Ball & Oct. 1-Nov. 15 & $2-3$ & $0-1 / 4$ & $6-8$ & $1-3$ & $7-15$ \\
\hline Clover, Berseem & Oct. 1-Nov. 15 & $15-20$ & $1 / 4-1 / 2$ & $8-10$ & $3-5$ & $10-20$ \\
\hline Clover, Crimson & Oct. 1-Nov. 15 & $20-25$ & $1 / 4-1 / 2$ & $8-10$ & $3-5$ & $10-20$ \\
\hline Clover, Red & Oct. 1-Nov. 15 & $10-15$ & $1 / 4-1 / 2$ & $8-10$ & $3-5$ & $10-20$ \\
\hline Clover, Subterranean & Oct. 1-Nov. 15 & $15-20$ & $1 / 4-1 / 2$ & $6-8$ & $1-3$ & $7-15$ \\
\hline Clover, White & Oct. 1-Nov. 15 & $3-4$ & $0-1 / 4$ & $6-8$ & $1-3$ & $7-15$ \\
\hline Fescue, Tall & Nov. 1-Dec. 15 & $20-25$ & $1 / 4-1 / 2$ & $4-8$ & $2-3$ & $15-30$ \\
\hline Medic & Oct. 1-Nov. 15 & $\begin{array}{l}10-15 \\
\text { rates differ }\end{array}$ & $0-1 / 4$ & $6-8$ & $1-3$ & $7-15$ \\
\hline Oats for forage & Sept. 15-Nov. 15 & $100-120$ & $1-2$ & $8-12$ & $3-5$ & $7-15$ \\
\hline Pea, Austrian Winter & Oct. 1-Nov. 15 & $40-60$ & $1 / 2-1$ & \multicolumn{3}{|c|}{ Poor grazing tolerance. Better suited as a hay or silage crop. } \\
\hline Rye for forage & Oct. 15-Nov. 15 & $90-120$ & $1-2$ & $8-12$ & $3-4$ & $7-15$ \\
\hline Ryegrass, Italian (annual) & Oct. 1-Nov. 15 & $20-30$ & $0-1 / 2$ & $6-12$ & $3-4$ & $7-15$ \\
\hline Sweetclover & Oct. 1-Nov. 15 & $10-15$ & $1 / 4-1 / 2$ & $8-10$ & $3-5$ & $10-20$ \\
\hline Turnips & Oct. 1-Nov. 15 & $5-6$ & $1 / 4-1 / 2$ & $6-8$ & $2-3$ & varies \\
\hline Vetch, hairy & Oct. 1-Nov. 15 & $20-30$ & $1-2$ & $6-8$ & $3-4$ & varies \\
\hline Wheat for forage & Oct. 15-Nov. 15 & $90-120$ & $1-2$ & $8-12$ & $3-5$ & $7-15$ \\
\hline $\begin{array}{l}\text { Triticale for silage or use } \\
\text { in blends }\end{array}$ & Oct. 15-Nov. 15 & $90-120$ & $1-2$ & \multicolumn{3}{|c|}{ Harvest for silage at milk or soft dough stage of maturity. } \\
\hline
\end{tabular}

Table 2. List of species and recommended cool-season forage varieties for Florida, based on three-year, multi-location trials in partnership with the University of Georgia and Auburn University.

\begin{tabular}{|c|c|c|}
\hline Species & Recommended Varieties for Florida ${ }^{1}$ & Observation $^{2}$ \\
\hline Alfalfa & Alfagraze 600RR, Bulldog 805 & \\
\hline Arrowleaf Clover & Blackhawk, Apache & \\
\hline Ball Clover & Don, Grazer's Select & \\
\hline Berseem Clover & Bigbee, Frosty & \\
\hline Crimson Clover & Dixie, AU-Robin & \\
\hline Red Clover & Barduro, Red Ace, Southern Belle, FL24D & \\
\hline White Clover & Louisiana S-1, Ocoee, Osceola, Regal Ladino, Regalgraze & \\
\hline Lupine & Tifblue & \\
\hline Medic & Amarillo, Frost, Tifwhite & \\
\hline Oat & Legend 567, Horizon 720, Horizon 306, Horizon 270*, RAMLA $99016^{*}$ & ${ }^{*}$ More susceptible to crown rust. \\
\hline Rye & FL401, Kelly Grazer III, Wrens Abruzzi, Bates RS4, Elbon, Oklon, Maton, Maton II & \\
\hline Ryegrass (early season) & $\begin{array}{l}\text { Attain, Big Boss, Diamond T, Earlyploid, Flying A, Frostproof, Lonestar*, Marshall }{ }^{*} \text {, } \\
\text { Maximus*, Nelson, Prine, TAMTBO, Tetrastar }\end{array}$ & \multirow[t]{3}{*}{$\begin{array}{l}\text { *Susceptible to rust and/or gray } \\
\text { leaf spot. }\end{array}$} \\
\hline Ryegrass (late season) & Attain, Big Boss, Marshall*, Maximus*, Nelson, Prine, TAMTBO, Tetrastar & \\
\hline Ryegrass (long-season) & $\begin{array}{l}\text { Attain, Big Boss, Diamond T, Earlyploid, Flying A, Lonestar*, Marshall*, Maximus*, } \\
\text { Nelson, Passerel Plus, Prine, TAMTBO, Tetrastar }\end{array}$ & \\
\hline \multicolumn{3}{|c|}{$\begin{array}{l}\text { 'Varieties selected based on their recent three-year, multi-location performance. Other varieties that have not been tested may perform well in } \\
\text { Florida. } \\
{ }^{2} \text { See text for more information. }\end{array}$} \\
\hline
\end{tabular}

